\title{
The Role of Technological Business Incubators in Supporting and Developing Marketing Capabilities for Entrepreneurship Business and Small Projects in Jordan
}

\author{
Mohammad Mansour Abu-Jalil ${ }^{1}$ \\ ${ }^{1}$ Faculty of Administrative and Financial Sciences, Philadelphia University, Jordan \\ Correspondence: Mohammad Mansour Abu-Jalil, Faculty of Administrative and Financial Sciences, Philadelphia \\ University, Jordan. E-mail: islyzd@yahoo.com
}

Received: December 7, 2016

Accepted: December 29, 2016

Online Published: January 6, 2017

doi:10.5539/ibr.v10n2p82

URL: http://dx.doi.org/10.5539/ibr.v10n2p82

\begin{abstract}
This research aimed to identify the role of technological business incubators in supporting and developing marketing capabilities for entrepreneurship business and small projects in Jordan. The research population included all personnel and owners of the small entrepreneurship, either those projects were incubated or not. The sample of the study consisted of (400) respondents. It was concluded that there was a role for the services provided by technological business incubators of, (administrative services, financial services, professional services, follow-up and personal services) in supporting and developing the marketing capabilities in business entrepreneurship and small projects in Jordan. The averages for those services were of a high level of Importance. In light of the findings' it was recommended to continue to provide accounting services and billing for business entrepreneurship and small businesses, and to emphasized the importance of holding specialized training courses for business entrepreneurship and small projects.
\end{abstract}

Keywords: technological business incubators, supporting and developing marketing capabilities, entrepreneurship business, small projects, Jordan

\section{Introduction}

Recently, business incubators appeared as one of the solutions to create new job opportunities for the local human resources, especially in the entrepreneurship and small business projects field. These incubators are considered effective for utilization of national human wealth to achieve number economic and social gains in light of high rates of unemployment, and the increasing number of graduates of higher education institutions in Jordan.

Entrepreneurship and small projects represent one of the trends followed by worlds' developed and developing countries, including Jordan. Such projects are considered to be among the important fields in the economics of advanced industrial countries as well as the developing ones. They contribute to moving the economic growth and the achievement of the objectives of the comprehensive support and developmental plans economically and socially. Moreover, entrepreneurship and small projects are considered to be the first core in founding and building small and large business organizations at their different organizational levels, which enable such organizations to enter the markets.

Entrepreneurship and small projects in the various sectors to which they belong need favorable conditions for work. Moreover, they need activities to support their operations at least in the early years of their life circles, as these entrepreneurship and small projects fail to meet the environment conditions, related to both infrastructure and dealing with the domestic and international markets. If this is true to the existing projects, the case will be more difficult for the new ones.

Since marketing capabilities are based on determining wishes and needs of the targeted customers, adapting entrepreneurship and small projects to marketing strategies in the target market must be within the frameworks and axes towards the achievement of these needs and wishes. And in a way that is suitable with goods and services characteristics that will be marketed from the four elements marketing mix, which represent the main axis in the marketing strategy. The degree of the integration of these elements is done by the marketing mix, which can be adapted according to the different conditions in the market. 
Therefore, it is necessary to create systems to support the creative abilities that have a direct impact on the marketing capabilities of these entrepreneurship and small projects. In addition, it is important to activate the role of business incubators to support entrepreneurship and small projects as well as to support and develop creative scope to ensure opportunities of survival, growth and continuity.

\section{Problem of the Study}

Despite the importance of the role and of business incubators in the aspect of support and development of marketing capabilities for business entrepreneurship and small businesses, which is in theory and practical hard-core of economic growth and overall social progress?

Also, despite the fact that recognizing their importance and giving them the importance began by all governments, particularly in developing countries, which is reflected in the plans and policies in order to support. But academic research in this field is still weak, especially in Jordan. Studies that have dealt with this important sector are relatively few.

The researcher believes that the limitation of this research in this aspect will hinder assessing the current status of these incubators work. Thus standing is on some important aspects in developing their performance in serving the entrepreneurship business sector and small project which is relatively large in Jordan.

This motivated the researcher to search this field in general, focusing on studying and evaluating the role of business incubators in supporting and developing marketing capabilities for business entrepreneurship and small enterprises in Jordan. Those projects whose success is apparent in fulfilling their role in economic and social development supporting process.

Business incubators play an important role in creating a new jobs opportunities and reducing unemployment. In addition, they improve income and living level for individuals. Moreover, they contribute in reducing poverty, as well as contributing to the empowerment of the owners of these businesses and projects integration in supporting of economic and social developing process (Issawi, 2010).

As business incubators has a role in supporting and developing marketing capabilities for business entrepreneurship and small businesses, the present study raises the following question: Is there a role for the services provided by business incubators (administrative services, financial services, professional services, follow-up and personal services) in supporting and developing marketing capabilities for business entrepreneurial and small project in Jordan?

\section{Purpose of the Study}

This research aimed to identify the role of business incubators in the services provided by these incubators represented in (administrative services, financial services, professional services, follow-up and personal services) in supporting and developing marketing capabilities for business entrepreneurship and small enterprises in Jordan.

\section{Significance of the Study}

The importance of the present study lies in dealing with one of most important modern mechanisms in promoting growth and economic prosperity, that is, business incubators, as well as the importance of this sector entrepreneurship and small project- which is usually characterized by a number of characteristics capable to solve economic and social problems, such as unemployment and absorbing the growing numbers of graduates of higher education institutions.

Thus, this research, including the findings will be the nucleus of constituent for later research in the field of evaluating the role of Jordanian business incubators, in addition to drawing the attention of decision-makers in these incubators about the importance of supporting and developing the marketing capabilities of the sector of entrepreneurship and small businesses if they want to have their continuity, survival and growth under the current global challenges.

\section{Theoretical Framework}

\subsection{Concept of Business Incubators}

The business incubator is defined as an integrated system dealing with each project at the beginning stages as if it is a new born requiring intensive care and overall interest to protect it from dangers, also to provide it with continuous power and gradually push it to become powerful and able to remain, self-reliant, equipped with the ability of continuity and success (Shalaby, 2001).

The business incubator is also defined as: "an institution standing alone with a prestigious personality. Provides a 
number of services and facilities for small projects and help them to overcome the burden of the first stages, it may be a private or mix or State institution Business Incubator, that gives her strong support (Rahim, 2003).

The main concept of business incubators definition (ESCWA), which showed that business incubator is an integrated package of services, facilities, mechanisms of support counseling provided to entrepreneurs who want to establish their entrepreneurial small, projects and specific period of time, in order to reduce first stage costs for their projects, which is considered the most difficult and critical stage for most entrepreneurial and small business projects (Mirage, 2010).

Business Incubators also were also defined as "government or private construction that practice activities aiming to provide counseling, advice, supporting services, financial, administrative and technical assistance to businesses and small industries, both in the early stages of activity or during the various stages that institutions pass through. These incubators provide opportunities for partnership in office services, equipment, machinery, lease and transfer of technology etc ( Hinawi, 2011).

The National Business Incubators Association (NBIA) defined Business Incubator as a tool for economic development be designed to accelerate the growth, success of small and medium-sized business organizations, through the system of resources, services, support and assistance for their activities, in order to present successful organizations, able to grow and continue after the incubator leaves and quits submission of these services (Lavrow and Sample, 2012)

The researcher defines business incubators as an environment having dynamic nature with all the human, financial, and technological facilities in order to support and develop the marketing capabilities for business entrepreneurship and small projects in Jordan, through presenting administrative services, financial services, professional services, follow-up and personal services and providing protection and care, especially at the first stages of these projects.

The following is a brief discussion about it:

1- Administrative Services: administrative services and facilities provided by business incubators to entrepreneurial business and small projects owners, such as establishment of projects, accounting services, preparing billing, equipment rent etc.

2- Financial services: financial services and facilities provided by business incubators to entrepreneurial business and small projects owners, such as assistance in getting finance through finance companies or government programs to finance such projects.

3-Specialized services: the specialized services and facilities provided by business incubators to entrepreneurship and small projects owners such as product development consulting, packaging, pricing, product management, and marketing services etc.

4- Follow-up and Personal Services: follow-up and personal services provided by business incubators for entrepreneurial business and small projects owners, such as advice, quick and direct helping etc.

\subsection{Business Incubators Roles}

Business incubators contribute in organizing and providing care, assistance and support to business entrepreneurship and small businesses, local community development, supporting economic development, human resources development and creating jobs, solve a specific problem. In addition to supporting and sponsoring entrepreneurs who have no resources to start applying their ambitious ideas, this will generate a positive impact on the economic, social and vacancy structure of the country.

The major roles of business incubators in this aspect, are the following: (Jabr, 2010)

1. Encouraging and supporting entrepreneurship and small business projects and increasing their chances of success by providing administrative, training, marketing and consulting services.

2. Giving opportunities for individuals to establish entrepreneurship and small businesses which have accounted risks, with providing legal needed services. Such as procedures of establishment, registration and writing license contracts.

3. Providing job opportunities especially for university graduates and help them to overcome the obstacles they face at the beginning of their working lives, and contribute to reduction the poverty and unemployment problem.

4. Finding appropriate marketing cannel through a package of services offered by these incubators.

5. Directing Investments towards high- productivity sectors and transfer labors to the most productive sectors in order to improve the living conditions of low-income people. 
6. Facilitate access to sources of funding and assistance to projects that relate to those wishing to invest in these projects in progress.

7. Developing and vitalizing the local community through developing business environment, establishing projects, making incubator be the regional and local development nucleus, and a center for spreading the spirit of free business among those who wish to join market.

8. Infrastructure provision, where the incubators provide the projects with the basic facilities, required laboratories, plants, equipment, and additional requirements of devices, programs, information technology services and communications networks.

In the effort to improve the economic development, incubators could play a dual role, especially incubators in universities, through operating them as experimental constructions to shift research results to commercial products and services on the one hand. Moreover, creating is a suitable environment for training owners of new business on the other hand. Through contact with investment institutions, incubators can support the effective use of available capital, as well as the role of incubators that they play in strengthening the bonds of cooperation between the private and public sectors in overall economic and social development (economic and social Commission for Western Asia-ESCWA Committee, 2003).

The researcher believes that entrepreneurship and small business projects in the various sectors, to which they belong, need favorable conditions of work they also need activities and mechanisms that support their operations at least in the early years of their life cycle, which in turn requires the embrace of those projects and provide foundations for its continuity through the establishment of incubators that depend on providing all forms of assistance from feasibility studies and funding sources through industrial and marketing investments and access to marketing and export services.

\subsection{Marketing Capabilities}

Marketing capabilities are complementary processes designed for the application of group of knowledge, skills, material and human resources that the Organization owns to create value and customers benefit in way that enables it to achieve a competitiveness (Chandler and Steven, 2004).

Marketing capabilities represent possibilities and capabilities of the organization; they mainly depend on the ability to distinguish the market and developing marketing mix strategy in order to know the needs and desires that satisfy customers and contribute to earn the highest degree of loyalty as a set of integrative processes used by the organization through which resources to add value to the inputs (sarwat, 2009).

Marketing capabilities are described as complementary processes between knowledge that is based on the tangible and intangible resources, in order to create high value for customers and generate that value, because these capabilities reflect the integrated set of processes that aim to apply the collective knowledge and skills. It also means the availability of resources and capabilities of the organization in order to increase its capacity to meet the customers' needs, as well as enable it to add the value that customers seek out and ability to compete for a long term (Tsai \& Shin, 2014).

Marketing capabilities integration are represented in building organization merit and enhancing its efficiency and effectiveness in performing its job at both internal and external levels. It is also represented in the ability to reprepare the efficiency and effectiveness in order to strengthen the capacity to deal with the surrounding environment, which is characterized by uncertainty and rapid change (Fang \& Zou, 2009)

Fahy et al, (2010) see that the marketing capabilities possessed by organizations are hard to be imitated by competitors because they are related to the organization itself. So that, they provide the organization experiences, new knowledge and additional capabilities to achieve competitive advantage compared with organizations in same sector. Therefore, that reflects on achieving the highest levels of performance that the organization can respond through to continuous changes in customers' needs, preferences and their wishes.

Marketing capabilities are all the integrative processes through which the organization's resources are gathered, which mainly rely on knowledge with the material resources to find and create products, output of high-value. These capabilities come from integrate between knowledge of the employees and the degree of possession of skills and experiences that are enhanced by being constituted complex partial capabilities of experiences the accumulated knowledge or skills being used in organization processes. So that they can make coordination between the activities of and benefit from the assets owned (Qureshi, 2010).

Marketing capabilities can be developing through learning processes, that is when organizations and their marketing managements consistently and continuously apply their knowledge and skills in solving marketing 
problems. As the improvement and development of marketing capabilities requires that integrated operations based on harmony and alignment between cognitive resources of the Organization and its concrete resources in order to achieve and generate customers value (Slotegraaf \& Dickson, 2014).

Akroush et al, (2010) describes marketing capabilities as complementary processes designed to apply the organizations' knowledge, skills and resources in order to meet market's needs, as well as the ability to provide addition, value and usefulness to products which are able to meet the competition requirements.

Morgan et al, (2009) confirms that the marketing capabilities are complementary assets that contribute to achieving excellence in the overall organization performance. And that these capabilities will directly affect the yield to the organization's assets in a way that reflects the organization's better performance levels. On the other side, there is a degree of interaction and influence between the organization orientations and its marketing capabilities that enables it to match the continuous increase spreading its resources and adaptation with the marketing environment better than competitors.

The researcher believes that the marketing capabilities is knowledge, skills and expertise possessed by employed individuals and owners of entrepreneurship and small enterprises in Jordan, through the harmonization of what they own of the cognitive aspect and the concrete resources, in order to provide products that meet customers needs and desires and generate value to them.

\subsection{Review of Related Literature}

Shukri, (2012) conducted study to explain the role and importance of business incubators as a potential tool for recovery, development of the local economy by encouraging young people, university graduates who were initiators to create small businesses. The study concluded that there were challenges, obstacles facing business incubators in Palestine, the most important one that relate to the plan of sustainability, maintaining continued financing the necessary activities, in addition, lack of awareness among the young in the role of incubators and the importance of entrepreneurship establishment.

María, Santos, Juan and García, (2012) analyzed the organizational precedents of capabilities marketing and its impact on business performance. Their results indicated that internal marketing, or human resource management as clients internal organizational was a key factor in motivating employees effectively in the development of all marketing capabilities, strategic and operational. The study showed that marketing capabilities have a positive impact on customer satisfaction and loyalty, which ultimately lead to better organizational performance in terms of sales, profits and market share.

Zahrani (2013) arrived at that material and human resources available in business incubators that have been incubated was high, and the Saudi Arabian business incubators provides creative and supporting performance aspects for small and medium projects in high degree. There was a strong and positive statistically significant relationship between the availability of financial and human resources in business incubators in Saudi Arabia, and the extent to which they are able to provide creative and supporting aspects of performance for small and medium project.

Cullen (2014) showed that the business incubator is a part of the big value series that combines projects which are related by the vital support system, such as local service providers (lawyers, accountants, companies service providers), to establish relationships that will continue after leaving the project of business incubator. Results also showed that there was bias towards the known standards, but there was a chance for improving the alignment to the market and incubation periods.

Finally, Mehdi (2015) found that incubators projects mainly aimed to promote entrepreneurship and supporting small projects to meet the first stage difficulties. The study showed there was significant positive relationship correlation between the projects incubator services and the promotion of entrepreneurship. The services associated in study (administrative, consulting, human resources development, finance, marketing, and technical) with enhancing entrepreneurship with a significant positive relationship.

\subsection{Knowledge Frontier}

Through a review of previous studies, the researcher noted the absence of studies regarding the role of technological business incubators in supporting and developing marketing capabilities for entrepreneurship business and small projects in Jordan. Therefore, this study is the first study dealing with this topic, especially in the Jordanian environment which has recent experience in this context. Some studies conducted in the Arab and Western environments and used some of the study variables, or some of its dimensions. The study population represents a group of entrepreneurial and small business projects that are important to local economic sectors in the growth of the Jordanian national economy. 


\subsection{Jordanian Context}

The importance of entrepreneurship and small enterprises business in Jordan is their ability to effectively contribute to the development and achievement of economic and social objectives. This includes economic growth, create jobs vacancies, and poverty reduction. Entrepreneurship and small enterprises business make economic cooperation among the national sectors, encourage innovation, attract foreign investment, utilize local resources, extend of markets, develop human and technical capacities, and enhance competitiveness.

Entrepreneurship and small enterprises in Jordan warranty sufficient income for individuals, personal satisfaction, and self-realization for small enterprises owners and their family. They also contribute to the development of new jobs and reduce unemployment levels in the Jordanian society. In addition, they the launch of new types of goods and products as well as services, that lead to the emergence of new markets.

Entrepreneurship and small businesses in Jordan met the terms of success in the local level. According to the Ministry of Planning data for 2016, they contribute in more than 50 per cent of GDP, with size of 98.5 per cent of the total institutions. According to the Amman Chamber of Industry the number of entrepreneurship and small businesses is 107175 projects. Moreover, there are 900 medium enterprises and 165 large companies. These figures reveal that large companies in Jordan are less than 1 per cent, medium enterprises are 5 per cent, and entrepreneurial and small projects are 94 per cent. That means small and medium-sized companies make up 99 per cent of the Jordanian projects (Jordan Chamber of Commerce, Annual Report, 2016).

The Jordanian trend towards establishing business incubators is relatively new, as the Kingdom gives more interest towards development of knowledge economy as a primary platform for fields sustainable development of Jordanian society, development of small project sector to increase its contribution in local production, then generate ways of sponsoring and organizing.

Therefore, following the developed countries, many universities and industrial cities in Jordan it established a number of incubators. The goals of Jordan creativity centers (business incubators) in taking care of and developing creative ideas and transferring them from ideas and studies to successful business projects of profit and high value .

Incubators aim to encourage entrepreneurship and innovation in the Jordanian society. The Jordan Innovation Centers network (JICs Network) consists of currently six various incubators. Where incubators provided standardized services, but that each one is unique in which it offers to the target audience of entrepreneurs.

The most incubators in this field include:

1. Jordan Innovation Centre at Higher Council of Science and Technology (Amman).

It was established in 2003 and concerns about information and communication technology sector. It is the first specialized incubator in the field of information and communication technology in Jordan. The incubator aims to achieve the growth of the national economy by helping entrepreneurs in establishing competitive companies not only in domestic markets but also in the global markets. That is through managing them in specific building, provide the highest levels of logistics services, make strategies, and operating companies.

2. Jordan Innovation Center at College of Agriculture, Agricultural Business Incubator (The University of Jordan - Amman)

The agricultural business incubator was established at the College of Agriculture at the University of Jordan in 2005. It aims to develop industrial material and methods in agriculture. It is supported from the Higher Council for Science and Technology, the Ministry of Planning, and International Cooperation.

\section{Jordan Innovation Centre for Information Technology (Philadelphia University - Jerash )}

The center was established in 2005. It concerns about the engineering sector and the information and communications technology sector. The center aims to develop creative ideas and technology transfer then turn them into businesses. This is to increase businesses income to their owners by supporting creators, innovators, and new entrepreneurs. The center was established through a joint initiative among the University of Philadelphia, the joined Jordanian-European project EJADA, and Jordan Organization for Developing Economic Businesses.

\section{Jordan Innovation Centre at Al Hassan Industrial City (Irbid)}

The centre was established in 2006. It concerns about the engineering sector and light industry. The center consists of 10 incubators units. It also furnished with the latest equipment and devices with different sizes that suitable for number of the company members. 


\section{Jordan Innovation Centre at Al-Hussein Bin Abdullah II City (Karak)}

The centre was established in 2008. It concerns about the engineering sector, light industry, and the sector of information and communication technology. It was established by supporting from project of strategies for research and technological development and innovation, the Prince Faisal Center for Research - Mutah University.

\section{Jordan Innovation Centre at al-Hassan industrial city, IT incubator}

The centre was established in 2009. It concerns about information and communication technology sector. It also aims to create and stimulate small and medium-sized companies. It is specialization in the information technology industry in northern Jordan.

\section{Research Hypotheses}

Hypothesis 1: There is no role for administrative services provided by business incubators in supporting and developing marketing capabilities for business entrepreneurship and small projects in Jordan.

Hypothesis 2: There is no role for financial services provided by business incubators in supporting and developing marketing capabilities for business entrepreneurship and small projects in Jordan.

Hypothesis 3: There is no role for professional services provided by business incubators in supporting and developing marketing capabilities for business entrepreneurship and small projects in Jordan.

Hypothesis 4: There is no role for follow-up and personal services provided by business incubators in supporting and developing marketing capabilities for business entrepreneurship and small projects in Jordan.

Form 1. Research Model

Independent Variables
Dependent Variable

Supporting and Developing Marketing

Capabilities for Business Entrepreneurship

and Small Proiects in Jordan

\section{Definition of Terms}

Business Incubators: is an integrated package of services, facilities and mechanisms of supporting and consulting services provided for workers in the entrepreneurial and small projects business for a specific period of time, in order to reduce the start-up phase costs for businesses and projects, business incubators offer a range of services required by the establishment, supporting and developing entrepreneurship and small businesses,

Marketing capabilities: identifying customers' needs and meet them, follow-up changes and developments that occur in the target market, build a flexible mechanism for dealing with the changes and maintaining relationships with customers, product development, preparing personal training capable of performing the professional methods of marketing for entrepreneurship business and small projects.

Entrepreneurship and Small Projects: An organizational unit independent in its own, operated by organizer / pilot " entrepreneur " who in turn works on blending the production factors (land, resources, labor, and capital), in a way to direct it to produce or provide goods or service, then offer to the market, in order to achieve certain goals to increase production capacity in society during a certain period of time.

\section{Methodology}

\subsection{Population and Sample}

The population consisted of all personnel entrepreneurship and small projects owners in Jordan. (422) questionnaires were distributed among personnel in entrepreneurship and small projects owners, that spread all over Jordan using probability sampling, whether include or not, 400 questionnaires were statistically analyzed.

\subsection{Sources of Data Collection}

The researcher relied on two types of information sources, which are the secondary sources, such as management and marketing books, scientific articles, brochures and specialized periodicals in incubators business and marketing capabilities, as well as primary sources through constructing a questionnaire for the present study. To ensure validity and reliability of the questionnaire Cronbach's alpha coefficient was used, it was (\%86.3). 


\subsection{Statistical Methods}

Statistical methods package program of Social Sciences (SPSS) was used in data analysis, means were used to define the importance of the statements of the questionnaire; standard deviation. Simple regression linear analysis was used to test the hypotheses.

\section{Data Analysis and Hypotheses Testing}

Hypothesis 1: There is no role for administrative services provided by business incubators in supporting and developing marketing capabilities for business entrepreneurship and small projects in Jordan.

Following are tables that describe Means, Std. Deviation of each of the study variables.

Table 1. Means and Std. Deviations of Administrative services

\begin{tabular}{lcc}
\hline \multicolumn{1}{c}{ Question } & Mean & Std. D. \\
\hline incubator provide necessary services to entrepreneurship and small projects establishment & 3.79 & 0.79 \\
incubator offers accounting services and billing to entrepreneurship and small projects & 3.78 & 0.78 \\
The incubator prepares a plan of action to entrepreneurship and small projects & 3.90 & 0.73 \\
equipment and machinery needed for entrepreneurship and small projects are available in the & 3.86 & 0.88 \\
incubator & 3.86 & 0.80 \\
The incubator offers technical support to entrepreneurship and small projects & 3.82 & 0.87 \\
The incubator provided specialized training to entrepreneurship and small projects & $\mathbf{3 . 8 3}$ & $\mathbf{0 . 8 1}$ \\
\hline
\end{tabular}

Table 1 shows that Statement "The incubator prepares a plan of action to entrepreneurship and small projects" got the highest mean (3.90). its std. deviation was (0.73). Statement" incubator offers accounting services and billing to entrepreneurship and small projects" got the least mean (3.78), its std. deviation was (0.78). Standard deviation values indicate that the respondents' answers were closed, and that there is a strong agreement between respondents' views on the paragraphs. Using the simple regression analysis, Table 2 shows the results obtained when testing this hypothesis.

Table 2. Simple Regression Test: Hypothesis 1

\begin{tabular}{ccccc}
\hline & & & \\
\cline { 3 - 4 } & Sig. & $\begin{array}{c}\text { Unstandardized } \\
\text { Coefficients }\end{array}$ & $\begin{array}{c}\text { Standardized } \\
\text { Coefficients }\end{array}$ \\
\hline 0.000 & T & Std. Error & B \\
\hline
\end{tabular}

$\mathrm{R}=0.89 \quad$ Beta $=0.89 \quad \mathrm{R} 2=0.80$

Table 2 shows that the calculated ( $\mathrm{t}$ ) value of this hypothesis was (40.51) which is bigger than the referenced (t) value (1.645). Since the calculated ( $t$ ) value is bigger than the referenced $(t)$ value, the Nil hypothesis is rejected. Therefore, the study accepted the alternative hypothesis, which is "There is a role for administrative services provided by business incubators in supporting and developing marketing capabilities for business entrepreneurship and small projects in Jordan". This result was confirmed with the level of confidence $(\mathrm{p}=$ $0.00)$.

Hypothesis 2: There is no role for financial services provided by business incubators in supporting and developing marketing capabilities for business entrepreneurship and small projects in Jordan.

Table 3. Means and Std. Deviations of Financial services

\begin{tabular}{|c|c|c|}
\hline Question & Mean & Std. D. \\
\hline $\begin{array}{l}\text { The incubator has the ability to obtain finance through funding companies for establishing } \\
\text { entrepreneurship and small projects }\end{array}$ & 3.90 & 0.86 \\
\hline $\begin{array}{l}\text { The incubator organizes exhibitions and seminars and provides technical support to attract } \\
\text { financiers to initiate communication with the entrepreneurship and small projects }\end{array}$ & 3.81 & 0.79 \\
\hline $\begin{array}{l}\text { The incubator follows objective and accurate scientific mechanism in choosing } \\
\text { entrepreneurship and small projects that need support }\end{array}$ & 4.09 & 0.81 \\
\hline $\begin{array}{l}\text { The incubator sustain communication among financiers and operators of entrepreneurship } \\
\text { and small projects }\end{array}$ & 3.85 & 0.82 \\
\hline The incubator provides related economic statistics to entrepreneurship and small projects & 4.01 & 0.73 \\
\hline $\begin{array}{l}\text { The incubator has the ability to obtain finance through government programs to finance } \\
\text { entrepreneurship and small projects }\end{array}$ & 3.91 & 0.79 \\
\hline Financial services & 3.93 & 0.80 \\
\hline
\end{tabular}

Table 3 shows Statement "The incubator follows accurate scientific mechanism in choosing entrepreneurship and small projects that need support" got the highest mean (4.09), its std. deviation was (0.816). Statement "The incubator organizes exhibitions, seminars and provides technical support to attract financiers to initiate 
communication with the entrepreneurship and small projects" got the least mean (3.81), its std. deviation was (0.79). Standard deviation values indicate that the respondents' answers are closed, and that there is a strong agreement between respondents views on the paragraphs. Using simple regression analysis, table 4 shows the obtained results when testing this hypothesis.

Table 4. Simple Regression Test: Hypothesis 2

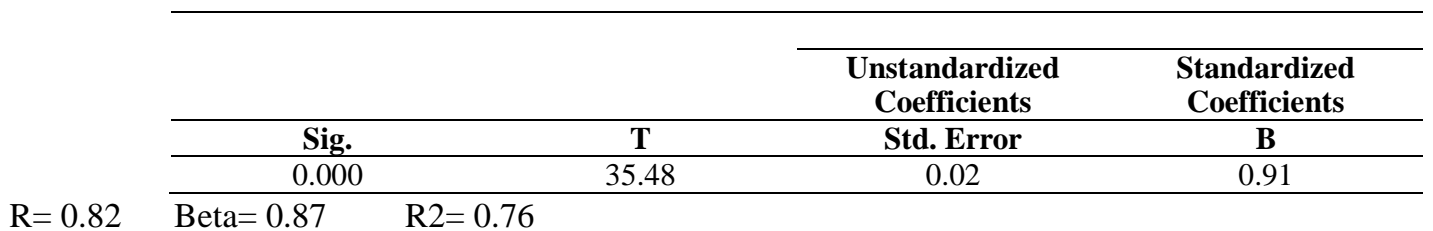

Table 4 shows that the calculated ( $t$ ) value of this hypothesis was (35.48) which was bigger than the referenced ( $t$ ) value (1.645). Since the calculated (t) value is bigger than the referenced (t) value, the Nil hypothesis should be rejected. Therefore, the study accepted the alternative hypothesis "There is a role for financial services provided by business incubators in supporting and developing marketing capabilities for business entrepreneurship and small projects in Jordan". This result was confirmed with a level of confidence $(p=0.00)$.

Hypothesis 3: There is no role for professional services provided by business incubators in supporting and developing marketing capabilities for business entrepreneurship and small enterprises in Jordan.

Table 5. Means and Std. Deviations of Professional services

\begin{tabular}{lcc}
\hline \multicolumn{1}{c}{ Question } & Mean & Std. D. \\
\hline $\begin{array}{l}\text { The incubator has marketing consulting to developing products produced by } \\
\text { entrepreneurship and small projects }\end{array}$ & 3.95 & 0.87 \\
\hline $\begin{array}{l}\text { The incubator holds meetings to provide detailed analysis for local and regional market } \\
\text { probable developments }\end{array}$ & 4.12 & 0.84 \\
\hline The incubator contributes in packaging the products of entrepreneurship and small projects & 4.06 & 0.81 \\
\hline $\begin{array}{l}\text { The incubator has group of expertise to develop the products produced by entrepreneurship } \\
\text { and small projects }\end{array}$ & 3.89 & 0.89 \\
\hline Professional services & $\mathbf{4 . 0 0}$ & $\mathbf{0 . 8 5}$ \\
\hline
\end{tabular}

Table 5 shows statement "The incubator holds meetings to provide detailed analysis for local and regional market probable developments" got the highest mean (4.122), its std. deviation was (0.848). Statement " The incubator has group of expertise to develop the products produced by entrepreneurship and small projects" got the least mean (3.895), its std. deviation was (0.896). Standard deviation values indicated that the respondents' answers are close, and that there is a strong agreement between respondents' views on the paragraphs. Using a simple regression analysis, table 6 shows the results obtained when testing this hypothesis.

Table 6. Simple Regression Test: Hypothesis 3

\begin{tabular}{cccc}
\hline & & & \\
\cline { 3 - 4 } & & $\begin{array}{c}\text { Unstandardized } \\
\text { Coefficients }\end{array}$ & $\begin{array}{c}\text { Standardized } \\
\text { Coefficients }\end{array}$ \\
\hline Sig. & $\mathbf{T}$ & Std. Error & B \\
\hline 0.05 & -1.96 & 0.10 & -0.20 \\
0.000 & 39.27 & 0.02 & 0.96 \\
\hline
\end{tabular}

$\mathrm{R}=0.89 \quad \mathrm{Beta}=0.89 \quad \mathrm{R} 2=0.79$

Table 6 shows that the calculated (t) value of this hypothesis was (39.27) which was bigger than the referenced (t) value (1.645). Since the calculated (t) value is bigger than the referenced (t) value, the Nil hypothesis should be rejected. Therefore, the study accepted the alternative hypothesis, which is "There is a role for professional services provided by business incubators in supporting and developing marketing capabilities for business entrepreneurship and small projects in Jordan". This result was confirmed with a level of confidence $(p=0.00)$.

Hypothesis 4: There is no role for follow-up and personal services provided by business incubators in supporting and developing marketing capabilities for business entrepreneurship and small enterprises in Jordan. 
Table 7. Means and Std. Deviations of Follow-up and personal services

\begin{tabular}{lcc}
\hline \multicolumn{1}{c}{ Question } & Mean & Std. D. \\
\hline The incubator offers advice and guidance to entrepreneurship and small projects & 3.87 & 0.74 \\
The incubator offers direct help to entrepreneurship and small projects & 3.90 & 0.85 \\
The incubator has efficiency and effective manager who follows-up, offers the services to & 3.85 & 0.82 \\
entrepreneurship and small projects & 3.86 & 0.64 \\
$\begin{array}{l}\text { Those who work in the incubator has the needed capacity and competency to support } \\
\text { entrepreneurship and small projects }\end{array}$ & $\mathbf{3 . 8 7}$ & $\mathbf{0 . 7 6}$ \\
Follow-up and personal services
\end{tabular}

Table 7 shows statement "The incubator offers direct help to entrepreneurship and small projects" got the highest mean (3.90) , its std. deviation was (0.853). Statement "The incubator has efficiency and effective manager who follows-up, offers the services to entrepreneurship and small projects" got the least mean (3.85), its std. deviation was $(0.82)$. standard deviation values indicated that the respondents' answers are close, and that there is a strong agreement between respondents' views on the paragraphs. Using the simple regression analysis, Table 8 shows the results obtained when testing this hypothesis.

Table 8. Simple Regression Test: Hypothesis 4

\begin{tabular}{ccccc} 
& & & & \\
\cline { 3 - 5 } & & & $\begin{array}{c}\text { Unstandardized } \\
\text { Coefficients }\end{array}$ & $\begin{array}{c}\text { Standardized } \\
\text { Coefficients }\end{array}$ \\
\cline { 2 - 5 } & Sig. & T & Std. Error & B \\
\cline { 2 - 5 } & 0.000 & 36.00 & 0.02 & 1.01 \\
\cline { 2 - 5 } & Beta $=0.87 \quad \mathrm{R} 2=0.76$ & & &
\end{tabular}

Table 8 shows that the calculated $(\mathrm{t})$ value of this hypothesis was (36.00) which was bigger than the referenced ( $\mathrm{t}$ ) value (1.645). Since the calculated (t) value is bigger than the referenced (t) value, the Nil hypothesis should be rejected. Therefore, the study accepted the alternative hypothesis, which is "There is a role for follow-up and personal services provided by business incubators in supporting and developing marketing capabilities for business entrepreneurship and small projects in Jordan". This result was confirmed with a level of confidence (p $=0.00$ ).

Table 9. Means and Std. Deviations of: Supporting and Developing Marketing Capabilities for Business Entrepreneurship and Small projects in Jordan

\begin{tabular}{|c|c|c|}
\hline Question & Mean & Std. D. \\
\hline $\begin{array}{l}\text { The incubators has sufficient numbers of workers in the field of marketing to take and } \\
\text { practice business and marketing activities }\end{array}$ & 3.74 & 0.61 \\
\hline $\begin{array}{l}\text { I see that business incubators are able to arrive at better marketing solutions to the problems } \\
\text { that face my project }\end{array}$ & 3.82 & 0.76 \\
\hline $\begin{array}{l}\text { I feel that workers of business incubators in the field of marketing have ideas and knowledge } \\
\text { which are characterized new }\end{array}$ & 3.81 & 0.66 \\
\hline $\begin{array}{l}\text { The incubator is careful to explain the methods of business achievement and the types of } \\
\text { skills that must be acquired by employees in marketing products of entrepreneurship and } \\
\text { small projects }\end{array}$ & 3.79 & 0.67 \\
\hline $\begin{array}{l}\text { The workers of incubators in the field of marketing have the ability and efficiency to } \\
\text { performing the vital role required to market entrepreneurship and small projects }\end{array}$ & 3.80 & 0.73 \\
\hline $\begin{array}{l}\text { Supporting and Developing Marketing Capabilities for Business Entrepreneurship } \\
\text { and Small projects in Jordan }\end{array}$ & 3.79 & 0.68 \\
\hline
\end{tabular}

Table 9 shows the statement "I see that business incubators are able to arrive at better marketing solutions to the problems that face my project" got the highest mean (3.82), its std. deviation was (.76). Statement "The incubators has sufficient numbers of workers in the field of marketing to take and practice business and marketing activities" got the least mean (3.74), its std. deviation was (.61). Standard deviation values indicate that the respondents' answers are close, and that there is a strong agreement between respondents views on the paragraphs.

\section{Findings}

The research arrived at the following findings:

1- There is a role for administrative services provided by business incubators in supporting and developing marketing capabilities for business entrepreneurship and small projects in Jordan. This means of that variable were of high level of importance. Results showed that incubators are preparing plan for entrepreneurship and small projects, in which equipment and machinery are available to those businesses and small projects. Moreover, they provide technical supporting services. 
2- There is a role for financial services provided by business incubators in supporting and developing marketing capabilities for business entrepreneurship and small projects in Jordan, the means of this variable were of high importance. Results showed that incubators follow accurate scientific mechanism for choosing entrepreneurship and small projects that need support. They also provide entrepreneurship and small projects with the related economic statistics. It was found that incubators have ability to obtain finance through government programs to finance entrepreneurship and small projects.

3- There is a role for professional services provided by business incubators in supporting and developing marketing capabilities for business entrepreneurship and small projects in Jordan. Means of this variable were of high level of importance. Results showed that incubators hold meetings to provide detailed analysis about local and regional markets and probable developments in both. They have contributions in packaging of products of entrepreneurship and small projects.

4- There is a role for follow-up and personal services provided by business incubators in supporting and developing marketing capabilities for entrepreneurship and small projects in Jordan. Means of this variable were of high level of importance. Results showed that incubators provide direct help to entrepreneurship and small projects, in addition to advice and guidance to those who are in charge of entrepreneurship and small projects.

The means of the variable supporting and developing marketing capabilities for entrepreneurship and small projects in Jordan were of high level of importance. Results showed that incubators are able to arrive at better solutions to marketing problems that faced employees and owners of entrepreneurship and small projects. Results also showed that employees of incubators in the field of business marketing have ideas and knowledge that are characterized new. And that they have efficiencies and abilities in performing the vital role required for marketing entrepreneurship and small projects.

The researcher believes that the findings of the study reinforce the importance of administrative services which were provided to entrepreneurial small businesses in Jordan. The idea about the establishment of business incubators is to develop mechanisms to embrace the owners of these businesses. The integration of creativity with small and medium enterprises guides to optimal utilization of resources. Therefore, it leads to the development of new useful ideas.

\section{Study Limitations}

The study used a questionnaire to collect data. Therefore, the answers of the participants were limited to the questionnaire items. Other studies could be conducted in the future and collect data based on in-depth interviews to collect more rich information about the role of technological business incubators in supporting and developing marketing capabilities for entrepreneurship business and small projects in Jordan.

\section{Recommendations}

The researcher presents a number of recommendations for incubators in Jordan. Recommendations are the following:

1- Continue to provide accounting services and billing for entrepreneurship and small projects.

2- Emphasize the importance of holding specialized training courses for entrepreneurship and small projects.

3- Organizing exhibitions, seminars and provide technical support to polarize financiers in order to initiate communication with entrepreneurship and small projects.

4- Building communication networks among funders and those who are in charge of entrepreneurship and small projects.

5- Providing expertise to developing the products of entrepreneurship and small projects.

6- Providing marketing consulting for developing the products of entrepreneurship and small projects.

7- Providing incubators with competent managers who are able to follow, manage and provide services to entrepreneurship and small projects.

8- It is important to those who work in incubators have competencies and capabilities needed to support entrepreneurship and small projects.

9- Increasing the number of incubators in Jordan and spreading them over all Jordanian cities. 


\section{References}

Akroush, M. N., \& Al-Mohammad, S. M. (2010). The Effect of Marketing Knowledge Management of Organizational Performance: An Empirical Investigation of the Telecommunication Organizations in Jordan. International Jordan of Emerging Markets, 5(1), 47. https://doi.org/10.1108/17468801011018266

Chandler, G. N., \& Steven, H. H. (2004). Market Attractiveness, Resource-Based Capabilities, Venture Strategies, and Venture Performance. Journal of Business Venturing, 9(4), 331-349. https://doi.org/10.1016/0883-9026(94)90011-6

Cullen, M. (2014). Business Incubation in the Eastern Cape: A Case Study. International Journal for Innovation Education and Research, 2(5), 76-89.

Economic and Social Commission for Western Asia (ESCWA). (2003). Technological Capacity-Building Initiatives During the Twenty first Century in the Member Countries, United Nations Publication, New York, USA.

Fahy, J., Hooley, G., Cox, J. T., Beracs, K. F., \& Snoj, B. (2010). The Development and Impact of Marketing Capabilities in Central Europe. Journal of International Business Studies, 31(1), 63-81. https://doi.org/10.1057/palgrave.jibs.8490907

Fang, E., \& Zou, S. (2009). Antecedents and consequences of marketing dynamic capabilities in international joint ventures. Journal of International Business Studies, 1(40), 743-759. https://doi.org/10.1057/jibs.2008.96

Hinawi, M. S. (2011). Business Incubators, Aleskandria, Egypt, University House for Publication and Distribution.

Issawi, I. (2010). Development in a Changing World, Al Shorouk publishing, printing and distribution, Amman, Jordan.

Jabr, F. S. (2010). Business Incubators, A Tool for Arab Development, Faculty of economic and business sciences, management, Constantine, 2, University- Abdelhamid Mehri. Journal of Economic Studies, 2, 41-67.

Jordan Chamber of Commerce. (2016). Annual Report.

Lavrow, M., \& Sample, S. (2012). Business Incubation Trend or Fad? Incubating the Start-up Company to the Venture Capital Stage: Theory and Practice, Ottawa- Canada - MBA.

Mahdi, J. (2015). The Impact of Incubator Projects in the Promotion of Entrepreneurship in Annaba. Journal of Economic Sciences, 16(2), 148-169.

María, J., Santos, L., Juan, A., \& García, N. (2012). Marketing Capabilities Development in Small and Medium Enterprises: Implications for Performance. Journal of CENTRUM Cathedra, 5(1), 24-42. https://doi.org/10.7835/jcc-berj-2012-0065

Mi'raj, H. (2010). Business Incubators, Mechanisms of Supporting Small and Medium Enterprises, The National Forum on Investment Opportunities of Ghardaia, The Reality and Challenges, The National Institute for Trade Ghardaia, Algeria.

Morgan, N. A., Douglas, W. V., \& Charlotte, H. M. (2009). Market Orientation, Marketing Capabilities and Firm Performance. Strategic Management Journal, 1(30), 909-920. https://doi.org/10.1002/smj.764

Qureshi, M. S. (2010). Determinants and Outcomes of Marketing Capabilities in New Technology Based Firms in Berlin, Germany: An Empirical Study, Doctorate Dissertation, Berlin.

Rahim, H. (2003). Business Incubators Systems as a Mechanism to Support Technological Innovation, Faculty of economic sciences, management, Ferhat Abbas University, Setif. Journal of Economic Sciences, management, 2, 164-181.

Sarwat, A. (2009). Marketing Capability, Strategy and Business Performance in Emerging Markets of Pakistan. IUB Journal of Social Sciences and Humanities, 7(2), 92-104.

Shalaby, N. M, (2001). How can Saudi Arabia benefits from Business Incubators and Technology Parks. Saudi Commerce and economic review magazine, 88(1), 29-36.

Slotegraaf, R., \& Dickson, P. (2014). The paradox of a marketing planning capability. Journal of the Academy of Marketing Science, 32(4), 371-385. https://doi.org/10.1177/0092070304265217 
Shukri, O. M. (2012). The Palestinian Experience in Business Incubators and their Role in the Development of a New Youth Work, Research Presented to the Conference of Youth and Development in Palestine: Problems and Solutions, Faculty of Commerce at the Islamic University, Gaza, Palestine.

Tsai, M. T., \& Shin, C. M. (2014). The Impact of Marketing Knowledge among Managers on Marketing Capabilities and Business Performance. International Journal of Management, 21(4), 524-530.

Zahrani, A. (2013). The Role of Business Incubators in the Creative Capacity of the Small and Medium Projects Development in the Kingdom of Saudi Arabia: An Empirical Study from the perspective of those in charge of these projects. Journal of Management and Economics, 3(83), 138-165.

\section{Copyrights}

Copyright for this article is retained by the author(s), with first publication rights granted to the journal.

This is an open-access article distributed under the terms and conditions of the Creative Commons Attribution license (http://creativecommons.org/licenses/by/4.0/). 